\title{
RELATIONSHIP OF THE PROTON FLUX INTENSITY WITH RELATIVE DISTANCE BETWEEN HARMONICS OF TYPE II RADIO BURSTS IN THE RANGE 25-180 MHZ
}

\author{
E.A. Isaeva \\ Institute of Radio astronomy of NAS of Ukraine, isaevaode@gmail.com
}

\begin{abstract}
In this work, the relative distance between the harmonics of type II radio bursts and its relationship with the intensity of the proton flux with an energy $>30 \mathrm{MeV}$ are studied.

The studied sample contains 112 solar proton events (SPE) for the period from 24-11-2000 to 20-12-2014 years, accompanied by type II radio bursts in the range of $25-180 \mathrm{MHz}$.

For analysis, we used the original recordings of the dynamic spectrum in the range of $25-180 \mathrm{MHz}$ from the Solar Radio spectrograph (SRS), as well as the original recordings of the proton flux intensity with an energy $>1$ $100 \mathrm{MeV}$ according to GOES data.

A comparative analysis showed that for the vast majority of solar proton events, the relative distance between the harmonics of a type II burst varies over time over a wide range. Moreover, each event is characterized by a gradual decrease in the relative distance to the minimum value with subsequent increase.

In this work, we also studied the relationship between the proton flux intensity of solar cosmic rays (SCR) and the relative distance between the harmonics of type II radio bursts at a given time. A comparative analysis showed that there is a fairly strong relationship between the proton flux intensity with an energy $>30 \mathrm{MeV}$ and the frequency $f_{1}$ at the fundamental harmonic, at which the minimum value of the relative distance between the harmonics of the type II burst is observed. It was shown that the lower the frequency $f_{l}$ at the fundamental harmonic, the higher the intensity of the proton flux.
\end{abstract}

Keywords: Solar proton events, proton flux intensity, type II radio bursts, relative distance between harmonics.

АНОТАЦІЯ. В роботі досліджено відносну відстань між гармоніками радіосплесків II типу і ії зв'язок 3 інтенсивністю потоку протонів з енергією > $30 \mathrm{MeB}$.

Досліджувана вибірка містить 112 сонячних протонних подій (СПП) за період з 24-11-2000 по 20-122014 роки, що супроводжуться радіо сплесками II типу в діапазоні 25-180 МГц.

Для аналізу були використані оригінальні записи динамічних спектрів в діапазоні 25-180 МГц з сонячного радіо спектрографа (СРС), а також оригінальні записи інтенсивності потоку протонів з енергією > 1 $100 \mathrm{MeB}$ за даними з GOES.

Порівняльний аналіз показав, що для переважної більшості сонячних протонних подій відносна відстань між гармоніками сплеску II типу змінюється з плином часу в широких межах. Причому, для кожної події ха- рактерно поступове зменшення відносної відстані до мінімального значення з подальшим зростанням.

У даній роботі також бул досліджен зв'язок інтенсивності потоку протонів сонячних космічних променів (СКП) з відносною відстанню між гармоніками радіо сплесків II типу в даний момент часу. Порівняльний аналіз показав, що існує досить сильний зв'язок між інтенсивністю потоку протонів з енергією $>30 \mathrm{MeB}$ і частотою $f_{l}$ на основній гармоніці, на якій спостерігається мінімальне значення відносної відстані між гармоніками сплеску II типу. Показано, що чим нижче частота $f_{l}$ на основній гармоніці, тим вище інтенсивність потоку протонів.

Ключові слова: сонячні протонні події, інтенсивність потоку протонів, радіо сплески типу II, відносна відстань між гармоніками.

\section{Introduction}

To date, many indications have been received that type II radio bursts are generated at shock wave fronts (Zheleznyakov, 1970; Wild and Smerd, 1972; Nelson and Melrose, 1985). In this case, quite often, on the dynamic spectrum, one can observe splitting of the burst band into two parallel strips, which behave similarly in both intensity and drift velocity (Wild and Smerd, 1972; Nelson and Melrose, 1985; Mann, 1995, 1996 ; Zimovets et al., 2012; Vasanth et al., 2014). Some authors believe that the strips can merge (Mann, 1995, 1996), thereby believing it quite appropriate to characterize the distance between them at a given time $t_{i}$ by the relative band width $\Delta f / f_{i, 1}=\left(f_{i, 2}-f_{i, 1}\right) /$ $f_{i, 1}$, where $f_{i, 1}$ is the radiation frequency.

The observed band splitting is usually associated with the plasma mechanism of radio emission. If the ratio of the characteristic frequencies of the bands $f_{i, 2} / f_{i, 1}$

approximately equal to 2 , then they speak of two harmonics (first and second) radiation generated by a source located either in front of or behind the front of the shock wave. If the value $f_{i, 2} / f_{i, 1}$ differs significantly from the integer value and is noticeably less than 2 , then this splitting is also associated with the plasma mechanism of radio emission. However, in this case, the generation occurs at one harmonic in front and behind the shock front (Smerd et al., 1974, 1975; Vrsnak et al., 2001, 2002; Zimovets, 2012; Vasanth et al., 2014), where the plasma density and the generated frequency of electromagnetic waves have significantly different meanings. 


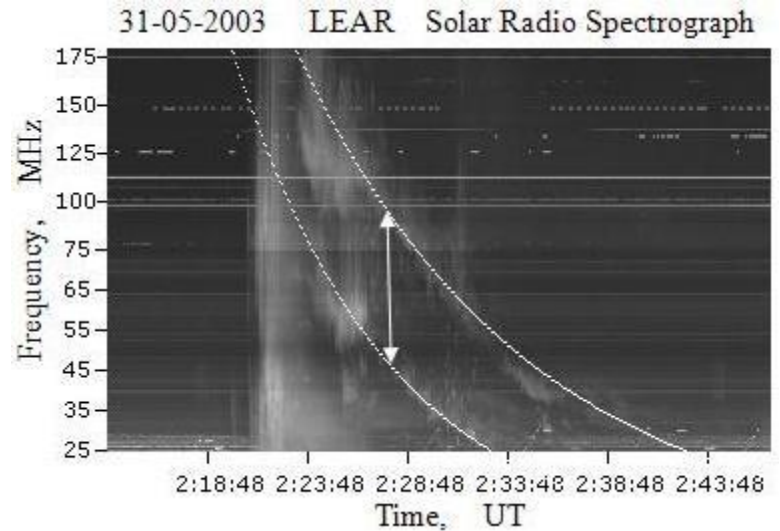

a)

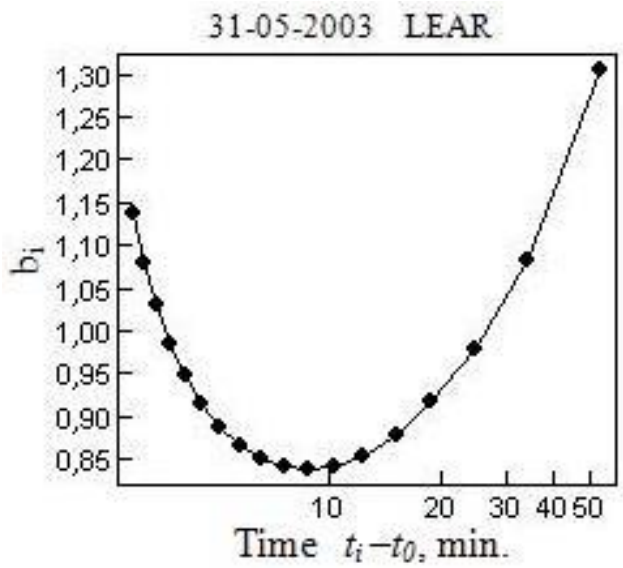

b)

Figure 1: a) Dynamic spectrum of a type II burst associated with a proton event on 31-05- 2003 year.

b) Change of the splitting $b_{i}$ over time $t_{i}$.

\section{Initial data and research results}

The studied sample contains 112 solar proton events (SPE) for the period from 24-11-2000 to 20-12-2014 years, accompanied by bursts II in the range $25-180 \mathrm{MHz}$. For the analysis, we used original records of the proton flux with an energy of $E_{p}>1-100 \mathrm{MeV}$ according to the data from GOES (https://satdat.ngdc.noaa.gov/sem/goes/data/new_avg/), original recordings of the dynamic spectrum in the range of 25$180 \mathrm{MHz}$ with Solar Radio Spectrograph (SRS) (http://www.ngdc.noaa.gov/stp/space-weather/solar-data/solarfeatures/solar-radio/rstn-spectral/), as well as a list of proton events (ftp://ftp.swpc.noaa. gov/pub/indices/ SPE.txt).

In figure 1a) shows an example of the dynamic spectrum of a type II radio burst associated with a proton burst on 31-05-2003 year. As can be seen, two bands can be distinguished corresponding to the main and second harmonics. In this work, we used a new regression model (Isaeva and Tsap, 2017) to approximate the type II burst harmonics (1), where $f_{i, j}$ is the frequency of the maximum of type II burst at a given harmonic at a given time $t_{i}, i$ reference number, $j$ - harmonic number, $a_{j}$ and $d_{j}$ - linear regression coefficients.

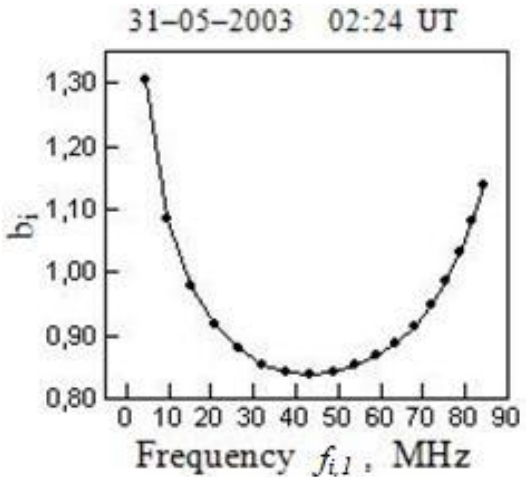

a)

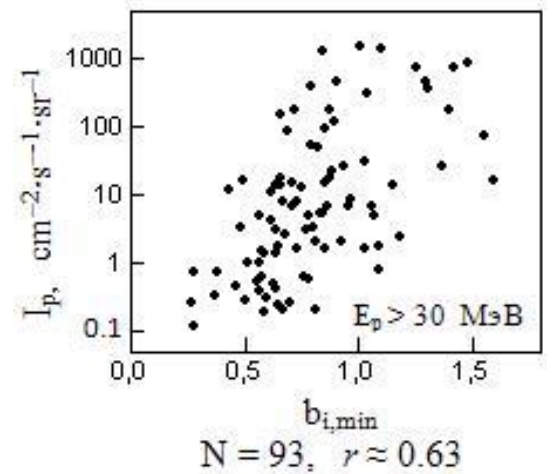

b)

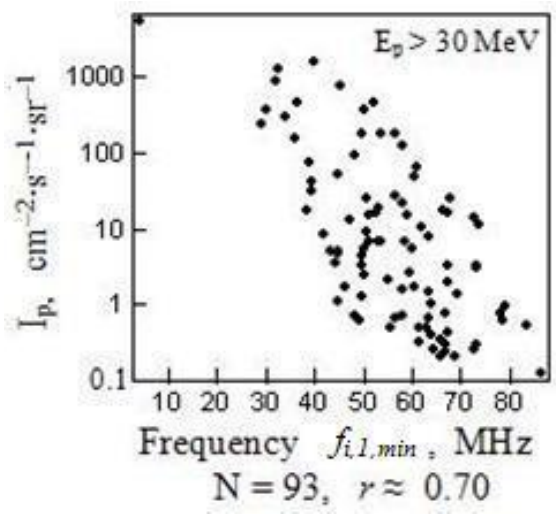

c)

Figure 2: a) Dependence of the relative distance $b_{i}$ on the frequency value $f_{i, 1}$ at the 1 st harmonic.

b) The relationship between the proton flux intensity $I_{p}$ and the relative distance $b_{i, \min }$.

c) The relationship between the proton flux intensity $I_{p}$ and the frequency $f_{i, 1, \min }$, at which the minimum value of the relative distance $b_{i, \min }$ between the harmonics of the type II burst is observed.

$$
\begin{aligned}
& \log _{10} f_{i, j}=a_{j} \cdot \sqrt{t_{i}}+d_{j} \\
& b_{i}=\frac{\left(f_{i, 2}-f_{i_{i} 1}\right)}{f_{i_{i} 1}}
\end{aligned}
$$

This model makes it possible to fairly accurately estimate the frequency drift velocity for $95 \%$ of type II bursts in the range $25-180 \mathrm{MHz}$, for which the correlation coefficient $r$ between the observed and calculated frequency values $r \geq 0.98$. For all events, the zero time moment $t_{0}$ 
corresponded to the beginning of a type II burst at the first harmonic at a frequency of $180 \mathrm{MHz}$.

In Figure 1a) an approximation of the harmonics of a type II burst is shown by thin white lines along the harmonics. The vertical arrow indicates the distance between harmonics in frequency $\Delta f=f_{i, 2}-f_{i, 1}$ at a given time $t_{i}$. For 112 type II bursts, the harmonic splitting width was studied, which was characterized by the relative distance $b_{i}$ between harmonics (2), where $f_{i, 1}$ and $f_{i, 2}$ are frequency values at 1 and 2 harmonics at a given time $t_{i}$.

In Figure $1 \mathrm{~b}$ ) shows a typical example of a change in the relative distance $b_{i}$ over time $t_{i}$ for a type II radio burst of 31-05-2003. A comparative analysis showed that over time, the width of the cleavage can vary over a wide range. It is shown that each event is characterized by a gradual decrease in the splitting width to the minimum value of $b_{i, m i n}$ with a subsequent increase. Moreover, for different events, the minimum value of the splitting $b_{i, \min }$ is observed in different frequency ranges. In Figure 2 a) the dependence of the relative distance $b_{i}$ on the frequency $f_{i, 1}$ at the 1-st harmonic is shown. In figure 2 a) it can be seen that for the event of 31-05-2003 year, the minimum splitting $b_{i, m i n}$ corresponds to a certain frequency $f_{i, 1, \min }$ at 1 harmonic.

Earlier in (Tsap Yu., Isaeva E., 2013), it was shown that there is a fairly strong relationship between the relative distance $b_{i}$ averaged over the entire time interval of a type II burst and the proton flux intensity $I_{p}$. Moreover, the relationship between $b_{i}$ and $I_{p}$ is much higher for protons with energies $>30-100 \mathrm{MeV}$, where the correlation coefficient $r$ between the studied quantities is $\approx 0.65-0.70$.

In the present work, we also investigated the relationship between the relative distance $b_{i}$ and the intensity of the proton flux $I_{p}$ with an energy $E_{p}>30 \mathrm{MeV}$.

A comparative analysis showed that there is a fairly strong relationship between the proton flux intensity $I_{p}$ and the minimum relative distance between the harmonics of the type II radio burst $b_{i, \min }$ (see Figure $2 \mathrm{~b}$ ), where the correlation coefficient $r$ between $I_{p}$ and $b_{i, \min }$ is approximately 0.63 , which is in full agreement with the previously obtained results in the work (Tsap Yu., Isaeva E., 2013).

Also in this work, we studied the relationship between the proton flux intensity $I_{p}$ and the frequency $f_{i, 1, \min }$ at which the minimum splitting $b_{i, \text { min }}$ is observed.

A comparative analysis showed that the relationship between $I_{p}$ and $f_{i, 1, \min }$ is much higher than between $I_{p}$ and $b_{i, \min }$, where the correlation coefficient $r$ between the studied quantities is $\approx 0.63$ and $\approx 0.70$, respectively (see Figure $2 \mathrm{~b}$ and $2 \mathrm{c}$ ).

It was shown that the lower the frequency $f_{i, 1, \min }$ at the fundamental harmonic, the higher the proton flux intensity $I_{p}$ (see Figure $2 \mathrm{c}$ ), where the correlation coefficient $r$ between the studied quantities is $\approx 0.70$.

\section{Conclusion}

As follows from the obtained results, the often observed evolution of the splitting of bands of type II radio bursts can be associated with a change in the density jump in front and behind the shock front, which is determined by the characteristics of both the shock wave and the environment.

The inhomogeneity of the source can also make a certain contribution, which leads to a stronger absorption of electromagnetic waves in the low-frequency or highfrequency emission band at the first harmonic.

A sufficiently strong relationship between the intensity of the SCR proton flux and the frequency $f_{l}$ at the first harmonic, at which the minimum value of the relative distance is observed, may be an additional parameter for diagnosing the flux of SCR protons.

\section{References}

Isaeva E., Tsap Yu.: 2017, Odessa Astron. Publ., 30, 222.

Mann G., Classen T., Aurass H.: 1995, Astron. and Astrophys., 295, 775.

Mann G., Klassen A., Classen H. et al: 1996, Astron. and Astrophys., Suppl. Ser, 119, 489.

Nelson G. \& Melrose D.: 1985, eds. D.J.McLean \& N.R.Labrum, 333.

Smerd S., Sheridan K., Stewart R.: 1974, eds. G.A.Newkirk, IAU Symp., 57, 389.

Tsap Yu., Isaeva E.: 2013, Cosmic Research, 51, №2, 108.

Smerd S., Sheridan K., Stewart R.: 1975, ApL, 16, 23.

Wild J. \& Smerd S.: 1972, ARA\&A, 10, 159.

Vasanth V., Umapathy S., Vrsnak B. et al.: 2014, Solar Physics, 289, 251.

Vrsnak B., Aurass H., Magdalenic J. et al.: 2001, Astron. and Astrophys., 377, 321.

Vrsnak B., Magdalenic J., Aurass H. et al.: 2002, $A \& A$, 396, 673.

Zheleznyakov V.: 1970, Radio-Emission of Sun and Planets, Oxford: Pergamon Press.

Zimovets I., Vilmer N., Chian A. et al.: 2012, Astron. and Astrophys., 547, id.A6, 13. 